\title{
Tissue-Engineered Tracheal Regeneration: Current Status
}

\author{
Yoo Seob Shin \\ Department of Otolaryngology, School of Medicine, Ajou University, Suwon, Korea
}

\section{조직공학적 기도재건의 현재}

신 유 섭

아주대학교 의과대학 이비인후과학교실

\author{
Received February 13, 2017 \\ Revised February 24, 2017 \\ Accepted February 24, 2017 \\ Address for correspondence \\ Yoo Seob Shin, MD, PhD \\ Department of Otolaryngology, \\ School of Medicine, Ajou University, \\ 206 World cup-ro, Yeongtong-gu, \\ Suwon 16499, Korea \\ Tel $+82-31-219-5262$ \\ Fax $+82-31-219-5264$ \\ E-mail ysshinmd@ajou.ac.kr
}

Tracheal regeneration is very challenging clinical demand because the trachea is not a simple windpipe, but a multilayered, complex structure. The tissue-engineering technique is widely accepted as promising strategy in tracheal regeneration. For successful regeneration, a substitute for trachea should provide not only appropriate laterally rigidity and longitudinally flexibility for sustaining the luminal shape of the trachea, but also favorable environment for respiratory ciliated epithelium, smooth muscle and blood vessel cells to regenerate. To date, a variety of materials such as polyglycolic acid, poly (lactic-co-glycolic acid), polycarprolactone, nanocomposite polymers and many naturally-derived scaffolds have been investigated. With these investigations, several clinical attempt of tracheal replacement with artificial trachea have been tried, but clinical outcome has not been quite satisfying. This article reviews the regeneration of $\mathrm{C}$-shaped cartilage, respiratory ciliated epithelium and neovascularization of artificial trachea, together with the difficulties, plausible options and future perspectives.

Korean J Otorhinolaryngol-Head Neck Surg 2017;60(4):153-7

Key Words Regenerative medicine $\cdot$ Scaffold $\cdot$ Stem cells $\cdot$ Tissue engineering $\cdot$ Trachea.

\section{서 론}

조직공학 및 재생의학(tissue engineering \& regenerative medicine)은 여러 가지 질병, 노화, 사고로 인해 기능을 상실한 장기를 재생시키거나 대체하기 위해 조직 이식물(tissue implant), 나아가 인공장기(artificial organ)를 개발하기 위한 다 학제 학문이다.,2) 일반적으로 환자 자신에게서 분리, 배양된 특정 세포를 생체적합한(biocompatible) 재료로 구성된 지지 체(scaffold)에 생착시키고, 생체활성인자(bioactive factor) 또 는 생체반응기(bioreactor)를 이용한 자극(stimulation), 분화 (differentiation) 과정을 통해 조직 재생을 유도한다. ${ }^{3)}$ 즉, 공

This is an Open Access article distributed under the terms of the Creative Commons Attribution Non-Commercial License (http://creativecommons.org/licenses/by-nc/4.0) which permits unrestricted non-commercial use, distribution, and reproduction in any medium, provided the original work is properly cited.
학적-생물학적 기술을 이용하여 우리 몸의 생체조직과 유사 하게 제작된 자가 조직의 대체제 및 인공장기를 이용하여 다 양한 임상적 질환을 해결할 수 있는 가능성을 제시하고 있다. 즉, 기존의 수술적 혹은 약물적 치료에 반응하지 않아 기능을 잃은 장기나 손상된 조직을 다양한 공학-생명과학-의학적 인 지식을 이용하여 재생시키는 접근방법인 것이다.

선천적 혹은 기타 질환으로 인해 발생한 기관(trachea) 전장 의 $50 \%$ 이상 기관결손(tracheal defect)의 경우 단단문합술 (end-to-end anastomosis)로는 재건이 불가능한 것으로 알 려져 있다.,5) 이러한 기관의 결손은 종양, 기관절개술, 선천성 질환, 기도삽관의 장기화 또는 다양한 종류의 기관손상에 의 해서 발생할 수 있으며, 이는 생존에 중요한 발성, 연하, 호흡, 점액섬모 청소능(mucociliary clearance), 호흡 항원에 대한 면역 등 기능의 저하를 일으킬 수 있다. ${ }^{6,7)}$ 기관은 단순한 원통 
형 구조가 아니라 내부의 C자 모양의 연골이 존재하며, 호흡 섬모 상피(respiratory ciliated epithelium) 및 연조직으로 구 성된 다층구조(multi-layered structure)이다. 일반 연조직에 비해 탄력성이 떨어지고 단단하며, 길이가 길고 주요 심혈관 조직과 접해 있어 치료가 어려운 해부학적 특징이 있고, 일단 손상이 되면 내부의 호흡 섬모 상피와 정상적인 연골이 재생 되지 않고 섬유화, 상처조직화에 의해 회복되어 일반적인 치 료에는 반응하지 않는 특징이 있다. 따라서 대안적 치료의 개발 이 시급한 상태이며, 조직공학적 기관재건(tissue-engineered tracheal regeneration)이 그중 한 방법으로 주목을 받으며 최근까지 여러 기초적, 임상적인 결과를 보여주고 있다. 하지 만 몇몇 희망적인 결과에도 불구하고, 조직공학적 기관재건 술을 직접 환자에게 적용하기에는 넘어야 할 장애물이 많은 것으로 판단되며, 본 논문에서는 최근까지 진행된 여러 재생 의학-조직공학적 기도재건의 연구결과들을 정리하여 앞으 로 나아갈 방향에 대해 고찰해 보고자 한다.

\section{조직공학적 기관재건의 필수 요소}

기관을 대체하기 위한 조직의 이상적인 조건은 여러 문헌에 서 보고된 바 있으며, 정리하면 Table 1과 같다. ${ }^{8-10)}$ 이 중 가장 중요한 것은 좌우에서의 압력에도 무너지지 않고 기도(airway) 를 유지하는, 측면강직도(lateral rigidity)와 두경부의 움직임 에도 파열되지 않는 종적유연성(longitudinal flexibility)으로 대별되는 기계적 특성(mechanical properties)이다.) 뿐만 아 니라 감염, 육아조직형성을 막고, 가래를 배출할 수 있는 호흡 섬모 상피 재생도 성공적인 기관재생을 위해 반드시 필요한 조건이다. 이외에도 생채적합성, 면역적합성, 혈관재생능, 및 소 아 환자의 경우 성장가능성 또한 인공기관 대체물이 해결해야 할 필수과제이다.

\section{C-자형 기관 연골재생(C-shaped tracheal cartilage regeneration)}

전술하였던 것처럼, 조직공학적 기관재생을 통해 기도(air-

Table 1. General requirements for trachea replacement

\begin{tabular}{l} 
Characteristics \\
\hline Biocompatibility \\
Airtight coverage \\
Proper strength to sustain airway \\
Permit rapid regeneration of respiratory epithelium \\
Minimal inflammatory response \\
Integration with surrounding tissues \\
Support neovascularization \\
Resistant to fibroblastic and bacterial invasion
\end{tabular}

way)를 유지하기 위해선 신생 인공기관(artificial trachea)의 기계적 강도 및 유연성이 무엇보다도 중요하다. 인체 내에서 이러한 기계적 특성은 C-자형 기관 연골과 주변 연조직의 보 강으로 유지되고 있다. 적절한 기계적 특성을 만족시키고 성 공적인 기관연골의 재생을 위해 먼저 고려해야 할 것이 지지 체의 선택이다.

생체 지지체는 독성이 없으면서, 인체 내 이식 시 혈액 응고 나 비정상 염증반응을 유도하지 않는 생체적합성과 대체하려 는 각각의 장기에 맞는 적절한 물리적 특성을 가져야 한다. 그 러나 현재까지 개발되어 적용되고 있는 소재들은 아직 해결 하지 못한 문제점들을 지니고 있다. 전통적으로 천연유래 지 지체(naturally-derived scaffold)는 조직공학 및 재생의학영 역에서 오랫동안 사용되어 왔다. 천연유래 지지체는 세포 전 달 및 침투유도(cell delivery \& recruitment), 세포생착(cell attachment), 생체적합성(biocompatibility), 생분해성(biodegradability), 연골재생(chondrogenesis)에서 장점을 갖지만, 기계적 강도는 약하며, 가공성이 떨어져 3차원적인 모양을 제작하는 데 어려움이 있다. ${ }^{11)}$ 대표적으로 콜라겐(collagen), ${ }^{12)}$ 피브린과 히알루론산(fibrin/hyaluronic acid), ${ }^{13,14)}$ 키토산(chitosan), ${ }^{15)}$ 돼지연골유래 지지체(porcine cartilage powder) ${ }^{16,17)}$ 등이 천연유래 지지체로써 기관재생에 시도되었다. 반면, 합성 지지체(synthetic scaffold)는 천연유래 지지체와 비교하여 우 수한 물성 및 가공성에서 장점을 가지며, 모양을 만들거나 조 작이 용이하나 낮은 생체적합성과 낮은 조직 재생능력으로 인해 세포생착, 연골재생 및 신생혈관 형성 등에서는 약점을 보인다. ${ }^{18)}$ 대표적으로 polyglycolic acid(PGA), polylactic acid/ PGA, poly(lactic-co-glycolic acid), polyester urethane, Pluronic F-27(Sigma-Aldrich, St. Louis, MO, USA) 등이 시도 되었으며, 합성지지체 단독 혹은 천연유래 지지체와 함께 사 용되어, 여러 동물 모델에서 어느 정도 성공적인 기관재생능을 보여주고 있다. ${ }^{18-21)}$ 최근에는 $3 \mathrm{D}$ 프린터에서 독성유기용매 없 이도 사용이 가능한 polycarprolactone이 각광을 받고 있다.22) 하지만 천연유래 지지체와 합성지지체 모두 여러 가지 면에서 해결해야 할 과제가 남아있는 것이 사실이다. 조직공학적 기관 재생에 사용하기 위한 지지체의 실용화를 위해서는 생체소재 의 특성으로 요구되었던 기관의 구조적 골격으로서 역할을 할 수 있는 물성, 세포의 생착과 증식능력 향상, 육아조직 없 는 주변조직과의 융화, 그리고 일정기간 이후 분해될 수 있는 생분해성 등이 넘어야 할 장애물이라 하겠다.

조직공학적 기관재생, 연골재생에 있어 지지체 이외에 중요 한 요소는 이식세포의 선택이다. 성공적인 연골재생을 위해서 선택할 수 있는 세포에는 연골세포(chondrocytes)와 여러 종류 의 줄기세포(stem cells)가 있다. 가장 먼저, 연골세포는 Vacanti 
등 $^{23)}$ 이 보고한 최초의 조직공학적 기관재생 연구에서도 사용 되었으며, 이후에도 C-자형 기관 연골재생을 위해 많은 연구 에서 사용되고 있다. ${ }^{14,16,19)}$ 역분화(de-differentiation)의 문제 점이 있기는 하지만 연골세포 배양, 증식 및 재생 연골의 체 외(in vitro) 생성은 잘 확립되어 있는 접근방법이다. ${ }^{24)}$ 면역반 응을 고려하여 자가(autologous) 혹은 동종(allogenic) 연골 세포를 사용할 것인지, 연골의 공여부로 선택이 가능한 기관, 비중격 혹은 이개연골 등 중에서 어느 곳을 선택할지는 아직 연구자에 따라 여러 의견이 있는 상태이다.

한 가지 세포공급을 통해 여러 조직을 동시에 재생하기 위 한 가장 이상적인 세포 종류인 줄기세포(stem cells) 또한 기관 재생을 위한 연구에 사용되어 왔다. 잘 알려져 있는 것처럼 줄 기세포는, 배아조직에서 얻어지거나 성인의 경우 특정 부위에 소량 존재하는 특별한 세포로서, 형질의 변화 없이 무한 증식 이 가능하고(self-renewal), 연골, 혈관, 신경, 근육 등 다양한 종류의 조직으로 분화(multipotent differentiation)할 수 있 음이 잘 알려져 있다. 이러한 줄기세포는 재생의료의 핵심 요 소로서 전 세계적으로 활발하게 연구가 진행되어 왔다. 줄기 세포 중 배아줄기세포(embryonic stem cells)의 경우 적절한 자극에 의해 거의 모든 종류의 세포 형태로 분화할 수 있으 나 윤리적 문제와 기형종(teratoma) 형성 등의 가능성으로 실 제 사용이 제한적이다. 성체 줄기세포(adult stem cells)는 모 든 종류의 세포로 분화하지 못한다는 단점이 있지만, 배아줄 기세포에 비해 윤리적인 논란에서 비교적 자유로운 이점을 가져, 재생의학에서 많이 연구되어 왔다. 성체 줄기세포는 다 양한 조직에서 발견되며, 골수(bone marrow), 피부의 기저층, 소장(small intestine)의 내막, 뇌 등에서 얻을 수 있다. 이 중 근육, 연골, 골 등 중간엽 조직 및 신경, 피부로 분화되는 중간 엽 줄기세포(mesenchymal stem cells, MSCs), 특히 골수 유래 (bone marrow-derived), 지방유래(adipose-derived) 중간엽 줄기세포가 기관재생 연구에 많이 사용되어 왔다. ${ }^{17,25,26)}$ 중간 엽 줄기세포는 특별한 부작용 없이 연골세포와 유사하게 성 공적인 연골재생을 유도하는 것으로 알려져 있다. 줄기세포 연구가 발전함에 따라서 유도만능 줄기세포(induced pluripotent stem cells) 또한 기관재생 연구에 시도되고 있다. ${ }^{27,28)}$ 유도만능 줄기세포란, 최종적으로 분화가 완료된 세포가 만 능분화능력(pluripotency)을 가지도록 인위적인 역분화 과정 을 거쳐 유도된 세포들을 말하며, 최근 많은 연구가 진행 중 이다. 하지만 기관재생에의 적용, 나아가 재생의학에의 임상 적 적용에는 아직 더 많은 연구가 필요한 상태이다.

\section{호흡 섬모 상피 재생(Ciliated respiratory epithelium)}

정상적인 기관에서 기관의 내면은 점액 분비 및 청소에 중요한
기능을 갖는, 섬모를 포함하고 있는 가성증층원주 상피(pseudostratified columnar epithelium)로 덮여 있다. ${ }^{29,30}$ 호흡상피 는 섬모 상피세포(ciliated columnar cells), 배상세포(goblet cells), 및 기저세포(basal cells) 등 다양한 기능을 가지는 세포 로 구성되어 있다.) 모든 세포들은 기저막에 닿아 있으며, 일부 분만 강 내(luminal surface)에 접촉되어 있다. 배상세포는 점액 (mucus)을 호흡상피 위로 분비하여 외부 세균 혹은 입자들을 제거하며, 더 나아가 감염, 염증 등에 대한 면역반응을 담당 한다. 섬모세포의 경우, 여러 개의 운동성을 갖는 섬모가 첨단 (apical side)에 존재하여 정돈된 움직임(coordinated movement)을 만들어 낸다. 이러한 움직임은 점액섬모 청소기능 (mucociliary clearance)에 중요한 역할을 한다. 기저세포는 기저막에 존재하고, 기도와는 접촉하지 않으며, 줄기세포와 비 슷한 특성을 보인다. 이러한 다층구조의 호흡 점막을 성공적 으로 재생시키지 못할 경우, 육아조직이 발생하며, 감염 및 점 액의 정체가 발생하여 치명적인 기도의 폐색이 발생하게 된다.

다양한 조직 유래 기관지 상피세포(airway epithelial cells)를 이용한 호흡 섬모 상피 재생이 시도되었다. 가장 많이 이용되었 던 원천(source)은 비갑개(turbinate) 혹은 비중격(nasal septum) 유래 호흡 섬모 상피이다. 공기-액체 계면 방식(air-liquid interface technique)의 배양방법을 통해, 비강조직 유래세포에서 성 공적으로 다층의 호흡상피를 배양할 수 있음이 입증되었다. ${ }^{6,31)}$ 이외에도 협부점막(buccal mucosa), 심지어는 피부 상피세포에 서도 기도상피를 분화시키는 연구 보고가 있어 왔으나 ${ }^{32,33)}$ 분화 과정이 매우 복잡하고 어려우며, 충분한 세포를 증식시키는 것 은 거의 불가능하여 추가적인 개선이 반드시 필요한 상태이다.

이렇게 호흡상피는 충분한 양을 채취하기가 쉽지 않으며, 실험실 환경에서 배양하여 증식하는 것이 쉽지 않아, 배아줄 기세포를 이용한 호흡 섬모 상피 분화 연구도 활발히 진행되 어 왔다. Coraux 등 ${ }^{34)}$ 은 배아줄기세포에서 섬모 상피, 기저세 포(basal cell), 배상세포(goblet cell) 등을 포함한 호흡상피 를 분화시키는 데 성공했다. 유사하게 만능유도 줄기세포에 서 호흡상피가 분화 가능함이 보고된 바 있다. ${ }^{27)}$ 내배엽 기원 인 호흡상피를 외배엽 혹은 중배엽 기원 조직이나 세포로부 터 분화시키는 시도는 성공률이 높지는 않은 상태이다. 같은 이유로 중간엽 줄기세포(MSCs) 기원 호흡상피 분화도 몇몇 보고를 제외하고는 아직까지는 성공적이지 못하다.

\section{조직공학적 기관의 인체 이식 (Transplantation of Tissue-Engineered Trachea)}

조직공학적 기관의 인체 이식은 몇몇 시도가 있어 왔지만, 
부분 결손의 재건이거나, 높은 합병증 발생률 및 치명률로 인 해 아직 안정적이며 성공적인 임상 결과를 보고한 방법은 개발 되지 않은 것이 현실이다. Omori 등 ${ }^{35)}$ 이 2005년 탈장수술 이 나 흥벽재건에 사용되던 합성지지체인 Marlex(polypropylene; Ethicon Inc., Somerville, NJ, USA)로 구성된 튜브를 콜라 겐(collagen)으로 코팅하고, 안쪽에 나선형 링(재질; polypropylene)을 보강하여 기관이식물을 제작하였고, 이를 이용해 서 갑상선 기관침범으로 인한 부분 기관결손(partial tracheal defect)을 성공적으로 재건한 것이 조직공학적 기관 인체 이식 의 첫 성공 보고이다. ${ }^{36)}$ 이후 2008년 Macchiarini 등 ${ }^{25)}$ 이 결핵 에 의한 난치성 기도 협착질환을 가진 30세 여성 환자에서 사 체(cadaver)에서 획득한 약 $7 \mathrm{~cm}$ 의 기관을 탈세포과정(decellularization)을 거치고, 수혜자 호흡상피세포 및 연골세포를 생물반응장치(bioreactor)를 이용 및 이식하여 성공적인 결과 를 보고하였다. ${ }^{37)}$ 이후 몇몇 연구자들이 세포제거방법의 개선 이나 주변조직 보강방법의 도입 등 이식방법의 개선을 통한 사 체 유래 탈세포 기관(cadaver-derived decellularized trachea) 이식 보고가 몇 차례 있었다. ${ }^{38,39)}$ Macchiarini 등다은 추가로 합성 nanocomposite [polyhedral oligomeric silsesquioxane poly(carbonateurea)urethane]와 환자 세포(autologous bone marrow mononuclear cells), 생물반응장치를 이용한 조직공 학적 기관재건 사례를 보고하여 성공적인 결과를 보여주는 듯 하였다. ${ }^{40)}$ 하지만, 최근 연구윤리 위반(scientific misconduct) 에 대한 대대적인 조사가 있었고, 의혹이 사실로 판명되어 학 계를 큰 충격에 빠뜨렸다. ${ }^{41-44)}$ 조사결과에 따르면 2011 2014 년까지 합성지지체를 이용한 기관이식수술을 받은 9명의 환 자 중 7명이 사망하고, 한 명은 이식된 기관을 제거한 것으로 밝혀졌다. 따라서 조직공학적 기도재건, 특히 원통형 결손의 경우는 인체 적용에 좀 더 연구가 필요할 것으로 생각된다.

\section{결 론}

재생의학-조직공학은 인체 내에 질병과 노화 및 사고로 인 해 손상된 조직을 적절한 조작을 통하여 재생시키거나, 외부 에서 인공적으로 만들어진 이식물을 이용하여 정상조직과 융 화(integration)시켜 조직 고유의 해부학적, 생리학적인 기능을 재현시킬 수 있는 종합적인 시도를 포함하고 있다. 의학, 생명 과학 이외에도 화학공학, 재료공학 등의 융합학문으로 시작 된 조직공학 및 재생의학은 그 태동으로부터 약 30여 년을 넘 지 않는 짧은 역사에도 불구하고 최근 많은 연구가 집중되고 있으며, 더불어 다양한 연구배경을 가지고 있는 연구자들의 학제 간 연구가 활발히 진행되고 있다. 적극적인 연구의 결과 로 개발된 새로운 조직공학적 기술들에 대한 다양한 임상시
험이 진행 중이며, 가까운 미래에는 실제 임상의학에 사용될 수 있기를 기대하고 있다.

20 세기에 들어서 기도재건에 대하여 재생의학-조직공학 적 관점에서 활발한 연구가 이루어지고 있다. 그렇지만 기관 의 기능과 구조, 이를 재생시키는 기술에 대한 연구가 깊어질 수록 기도재건이 단순한 도관(tube, windpipe) 재건이 아니며, 더 복잡하고 어려운 것임을 알 수 있다. 대표적으로 거부반응 및 염증반응을 최소화하는 점, 기도(airway)를 유지할 만한 물리적인 강도를 유지하는 점, 호흡상피를 적절하게 재생시 키는 점, 이식물에 신생혈관 형성이 잘 되도록 하는 점, 그리 고 육아조직의 생성 및 재협착을 방지해야 하는 점 등에 대 한 문제를 우선적으로 해결해야 할 것이다. 이러한 과제들을 하나씩 해결해 나간다면, 해부학적, 생리학적 특성을 온전하 게 가진 신생 기관의 제작 및 환자에의 적용이 요원하지 만 은 않을 것이다.

\section{Acknowledgments}

This research was supported by a grant from the Korea Health Technology R\&D Project through the Korea Health Industry Development Institute, funded by the Ministry of Health \& Welfare, Republic of Korea (grant number: HI14C2108).

\section{REFERENCES}

1) Polak JM, Bishop AE. Stem cells and tissue engineering: past, present, and future. Ann N Y Acad Sci 2006;1068:352-66.

2) Mao AS, Mooney DJ. Regenerative medicine: current therapies and future directions. Proc Natl Acad Sci U S A 2015;112(47):14452-9.

3) Atala A. Engineering tissues, organs and cells. J Tissue Eng Regen Med 2007;1(2):83-96.

4) Hertegård S. Tissue engineering in the larynx and airway. Curr Opin Otolaryngol Head Neck Surg 2016;24(6):469-76.

5) Law JX, Liau LL, Aminuddin BS, Ruszymah BH. Tissue-engineered trachea: a review. Int J Pediatr Otorhinolaryngol 2016;91:55-63.

6) Zhang H, Fu W, Xu Z. Re-epithelialization: a key element in tracheal tissue engineering. Regen Med 2015;10(8):1005-23.

7) Bogan SL, Teoh GZ, Birchall MA. Tissue engineered airways: a prospects article. J Cell Biochem 2016;117(7):1497-505.

8) Belsey R. Resection and reconstruction of the intrathoracic trachea. Br J Surg 1950;38(150):200-5.

9) Neville WE, Bolanowski JP, Kotia GG. Clinical experience with the silicone tracheal prosthesis. J Thorac Cardiovasc Surg 1990;99(4): 604-12; discussion 612-3.

10) Crowley C, Birchall M, Seifalian AM. Trachea transplantation: from laboratory to patient. J Tissue Eng Regen Med 2015;9(4):357-67.

11) Allen AB, Priddy LB, Li MT, Guldberg RE. Functional augmentation of naturally-derived materials for tissue regeneration. Ann Biomed Eng 2015;43(3):555-67.

12) Ott LM, Weatherly RA, Detamore MS. Overview of tracheal tissue engineering: clinical need drives the laboratory approach. Ann Biomed Eng 2011;39(8):2091-113.

13) Kim DY, Pyun J, Choi JW, Kim JH, Lee JS, Shin HA, et al. Tissueengineered allograft tracheal cartilage using fibrin/hyaluronan composite gel and its in vivo implantation. Laryngoscope 2010;120 (1):30-8.

14) Hong HJ, Lee JS, Choi JW, Min BH, Lee HB, Kim CH. Transplantation 
of autologous chondrocytes seeded on a fibrin/hyaluronan composite gel into tracheal cartilage defects in rabbits: preliminary results. Artif Organs 2012;36(11):998-1006.

15) Zang M, Zhang Q, Davis G, Huang G, Jaffari M, Ríos CN, et al. Perichondrium directed cartilage formation in silk fibroin and chitosan blend scaffolds for tracheal transplantation. Acta Biomater 2011;7 (9):3422-31.

16) Shin YS, Lee BH, Choi JW, Min BH, Chang JW, Yang SS, et al. Tissue-engineered tracheal reconstruction using chondrocyte seeded on a porcine cartilage-derived substance scaffold. Int J Pediatr Otorhinolaryngol 2014;78(1):32-8.

17) Shin YS, Choi JW, Park JK, Kim YS, Yang SS, Min BH, et al. Tissueengineered tracheal reconstruction using mesenchymal stem cells seeded on a porcine cartilage powder scaffold. Ann Biomed Eng 2015;43(4):1003-13.

18) Del Gaudio C, Baiguera S, Ajalloueian F, Bianco A, Macchiarini P. Are synthetic scaffolds suitable for the development of clinical tissueengineered tubular organs? J Biomed Mater Res A 2014;102(7): 2427-47.

19) Hong HJ, Chang JW, Park JK, Choi JW, Kim YS, Shin YS, et al. Tracheal reconstruction using chondrocytes seeded on a poly(Llactic-co-glycolic acid)-fibrin/hyaluronan. J Biomed Mater Res A 2014;102(11):4142-50.

20) Lee DY, Park SA, Lee SJ, Kim TH, Oh SH, Lee JH, et al. Segmental tracheal reconstruction by 3D-printed scaffold: pivotal role of asymmetrically porous membrane. Laryngoscope 2016;126(9): E304-9.

21) Kwon SK, Song JJ, Cho CG, Park SW, Kim JR, Oh SH, et al. Tracheal reconstruction with asymmetrically porous polycaprolactone/ pluronic F127 membranes. Head Neck 2014;36(5):643-51.

22) Chang JW, Park SA, Park JK, Choi JW, Kim YS, Shin YS, et al. Tissue-engineered tracheal reconstruction using three-dimensionally printed artificial tracheal graft: preliminary report. Artif Organs 2014; 38(6):E95-105.

23) Vacanti CA, Paige KT, Kim WS, Sakata J, Upton J, Vacanti JP, et al. Experimental tracheal replacement using tissue-engineered cartilage. J Pediatr Surg 1994;29(2):201-4; discussion 204-5.

24) von der Mark K, Gauss V, von der Mark H, Müller P. Relationship between cell shape and type of collagen synthesised as chondrocytes lose their cartilage phenotype in culture. Nature 1977;267(5611): 531-2.

25) Macchiarini P, Jungebluth P, Go T, Asnaghi MA, Rees LE, Cogan TA, et al. Clinical transplantation of a tissue-engineered airway. Lancet 2008;372(9655):2023-30.

26) Weiss DJ, Elliott M, Jang Q, Poole B, Birchall M; International Society of Cell Therapy Pulmonary Scientific Committee. Tracheal bioengineering: the next steps. Proceeds of an International Society of Cell Therapy Pulmonary Cellular Therapy Signature Series Workshop, Paris, France, April 22, 2014. Cytotherapy 2014;16(12): 1601-13.

27) Firth AL, Dargitz CT, Qualls SJ, Menon T, Wright R, Singer O, et al.
Generation of multiciliated cells in functional airway epithelia from human induced pluripotent stem cells. Proc Natl Acad Sci U S A 2014; 111(17):E1723-30.

28) El-Badrawy MK, Shalabi NM, Mohamed MA, Ragab A, Abdelwahab HW. Stem cells and lung regeneration. Int J Stem Cells 2016;9(1): 31-5.

29) Satir P, Christensen ST. Overview of structure and function of mammalian cilia. Annu Rev Physiol 2007;69:377-400.

30) Stannard W, O'Callaghan C. Ciliary function and the role of cilia in clearance. J Aerosol Med 2006;19(1):110-5.

31) Ross AJ, Dailey LA, Brighton LE, Devlin RB. Transcriptional profiling of mucociliary differentiation in human airway epithelial cells. Am J Respir Cell Mol Biol 2007;37(2):169-85.

32) Delaere PR, Vranckx JJ, Den Hondt M; Leuven Tracheal Transplant Group. Tracheal allograft after withdrawal of immunosuppressive therapy. N Engl J Med 2014;370(16):1568-70.

33) Liang L, Bickenbach JR. Somatic epidermal stem cells can produce multiple cell lineages during development. Stem Cells 2002;20(1): 21-31

34) Coraux C, Nawrocki-Raby B, Hinnrasky J, Kileztky C, Gaillard D, Dani C, et al. Embryonic stem cells generate airway epithelial tissue. Am J Respir Cell Mol Biol 2005;32(2):87-92.

35) Omori K, Nakamura T, Kanemaru S, Asato R, Yamashita M, Tanaka $\mathrm{S}$, et al. Regenerative medicine of the trachea: the first human case. Ann Otol Rhinol Laryngol 2005;114(6):429-33.

36) Omori K, Tada Y, Suzuki T, Nomoto Y, Matsuzuka T, Kobayashi K, et al. Clinical application of in situ tissue engineering using a scaffolding technique for reconstruction of the larynx and trachea. Ann Otol Rhinol Laryngol 2008;117(9):673-8.

37) Gonfiotti A, Jaus MO, Barale D, Baiguera S, Comin C, Lavorini F, et al. The first tissue-engineered airway transplantation: 5-year followup results. Lancet 2014;383(9913):238-44.

38) Delaere P, Vranckx J, Verleden G, De Leyn P, Van Raemdonck D; Leuven Tracheal Transplant Group. Tracheal allotransplantation after withdrawal of immunosuppressive therapy. N Engl J Med 2010; 362(2):138-45.

39) Elliott MJ, De Coppi P, Speggiorin S, Roebuck D, Butler CR, Samuel $\mathrm{E}$, et al. Stem-cell-based, tissue engineered tracheal replacement in a child: a 2-year follow-up study. Lancet 2012;380(9846):994-1000.

40) Jungebluth P, Alici E, Baiguera S, Le Blanc K, Blomberg P, Bozóky $\mathrm{B}$, et al. Tracheobronchial transplantation with a stem-cell-seeded bioartificial nanocomposite: a proof-of-concept study. Lancet 2011; 378(9808):1997-2004.

41) Vogel G. Trachea transplants test the limits. Science 2013;340(6130): 266-8.

42) Cyranoski D. Investigations launched into artificial tracheas. Nature 2014;516(7529):16-7.

43) Vogel G. Regenerative medicine. Report finds misconduct by surgeon. Science 2015;348(6238):954-5.

44) Vogel G. Scientific misconduct. Karolinska to reopen inquiry into surgeon's work. Science 2016;351(6273):546.

\section{정답 및 해설}

답 부갑상선암종(parathyroid carcinoma)으로 인한 원발성 부갑상선기능항진증(primary hyperparathyroidism) 및 갈색종양 (brown tumor)

해 설 부갑상선암종은 매우 드문 종양으로 40 대에 많고 여성에게 많이 발생한다. 임상적으로는 혈중 칼슘이 14 이상, 부갑상선 호르몬이 높은 정상값의 3 10배 이상, 림프절 전이가 의심되는 영상 소견, 갑상선 침범 및 성대마비, 신질환, 골질환이 동반되는 경우에는 암종을 의심하여야 한다. 위 환자는 갑상선에 침범이 있고 광범위한 갈색종양과 함께 부갑상선호르몬 이 1500 이 넘어가는 경우로 부갑상선암종으로 의심하였고, 갑상선엽절제술과 함께 중심 경부림프절 청소술을 시행하였다. 